\title{
Immune-mediated muscle wasting and cell survival - the tale of a curious gene
}

James A Ross

From 6th European Workshop on Immune-Mediated Inflammatory Diseases

Nice, France. 23-25 November 2011

\section{Background}

Cancer cachexia remains a major clinical problem with the majority of advanced cancer patients suffering from aspects of this complex syndrome. Two key features of cancer cachexia include anorexia and an acute phase response, both of which contribute directly to accelerated wasting. Some of the metabolic abnormalities in cancer cachexia are similar to those involved in trauma and sepsis and involve a systemic inflammatory response with profound alterations in liver metabolism, together with loss of lean body mass. Such depletion of lean tissue (principally skeletal muscle) is an important factor contributing to the decreased survival of cancer patients. Skeletal muscle is the main labile source of amino acids in the body and this muscle is broken down to provide amino acids to the liver for the continuing, relentless acute phase response which is a feature of cancer cachexia.

A novel $24 \mathrm{kDa}$, heavily glycosylated, cachectic factor which can trigger muscle proteolysis during the process of cancer cachexia was identified first from a cachexiainducing mouse tumor [1] and from the urine of patients with pancreatic carcinoma and weight-loss [2]. The factor was identified as being a product of the human cachexia associated protein (HCAP) gene [3] and was later referred to as proteolysis inducing factor (PIF) which had a small core peptide (PIF-CP) of less than $3 \mathrm{kDa}$ and was extensively glycosylated. This glycosylated factor was shown by us to drive the acute phase response and to induce an inflammatory response from human hepatocytes $[4]$ and other cell types $[5,6]$.

The story then became more complex. From work in an unrelated area, a peptide was identified as a neuronal survival peptide (YP-30) in rat neuronal cells subjected to oxidative stress [7] and this peptide proved to be identical

Tissue Injury \& Repair Group, University of Edinburgh, MRC Centre for Regenerative Medicine, Edinburgh, UK in sequence to the PIF-CP. The rat gene encoding the YP-30 peptide was cloned and named the DSEP gene [8]. Around the same time, and again in a completely unrelated area, a group in Tubingen, working on skin antibiotics, identified and cloned the dermcidin (DCD) gene [9] which produced the dermcidin antibiotic peptide DCD-1. The HCAP, DSEP and DCD genes are completely homologous. In a bizarre twist of biological fate this gene encodes different products derived from separate regions of the gene. One product is the 30 amino acid core peptide of proteolysis inducing factor (PIF-CP), which is identical to the YP-30 neuronal survival peptide, and an entirely separate product, the dermcidin antibiotic peptide DCD-1. In a further, unrelated area, the DCD gene was identified as a candidate oncogene in invasive breast cancer [10]. We later went on to demonstrate that the DCD gene encoding PIF-CP, YP-30 and DCD-1 could protect various tumour cells from oxidative stress and hypoxia $[11,12]$ and that the portion of the gene responsible for this protection was that encoding the PIF-CP/ YP-30 peptide [13]. Expression of the gene also appeared to confer a proliferative effect on cells.

\section{Aims}

The aim of this paper is to describe the biology of the dermcidin gene and to identify the portion of the gene responsible for inducing cell proliferation.

\section{Results and conclusion}

In this study, we confirm a proliferative effect of DCD overexpression in the HuH7 human hepatic cell line. The proliferation is abrogated by prevention of PIF-CP translation or inactivation of its calcineurin-like phosphatase domain by site-directed mutagenesis. Prevention of translation of the DCD-1 antibiotic peptide had no effect. Treatment of cells with a 30 amino acid synthetic PIF-CP induced an increase in proliferation. Pathway 
analysis revealed several gene networks involved in the cellular response to the peptide, one with VEGFB as a hub and two other networks converging on Fos and Myc.

\section{Acknowlegements}

Thanks to colleagues over many years and to funding from BBSRC, Prostate Cancer Charity, The Ralph Shackman Trust and The Melville Trust.

Published: 23 November 2011

\section{References}

1. Todorov P, Cariuk P, McDevitt T, Coles B, Fearon K, Tisdale M:

Characterization of a cancer cachectic factor. Nature 1996, 379:739-742.

2. Wigmore SJ, Todorov PT, Barber MD, Ross JA, Tisdale MJ, Fearon KCH: Characteristics of patients with pancreatic cancer expressing a novel cachectic factor. British Journal of Surgery 2000, 87:53-58.

3. Akerblom IE, Murry LE: Human Cachexia Associated Protein. US patent 5834192 Incyte Pharmaceuticals, Inc. (Palo Alto, CA); Issued 1998, expired 2006.

4. Watchorn TM, Waddell I, Dowidar N, Ross JA: Proteolysis-inducing factor regulates hepatic gene expression via the transcription factors NF(kappa)B and STAT3. FASEB J 2001, 15:562-564.

5. Watchorn TM, Waddell I, Ross JA: Proteolysis-inducing factor differentially influences transcriptional regulation in endothelial subtypes. Am J PhysiolEndocrinolMetab 2002, 282:763-769.

6. Watchorn TM, Dowidar N, Dejong CH, Waddell ID, Garden OJ, Ross JA: The cachectic mediator proteolysis inducing factor activates NF-kappaB and STAT3 in human Kupffer cells and monocytes. Int J Oncol 2005, 27:1105-1111.

7. Cunningham TJ, Hodge L, Speicher D, Reim D, Tyler-Polsz C, Levitt $P$, Eagleson K, Kennedy S, Wang Y: Identification of a survival-promoting peptide in medium conditioned by oxidatively stressed cell lines of nervous system origin. J Neurosci 1998, 18:7047-7060.

8. Cunningham TJ, Jing H, Akerblom I, Morgan R, Fisher TS, Neveu M: Identification of the human CDNA for new survival/evasion peptide (DSEP): studies in vitro and in vivo of overexpression by neural cells. ExpNeurol 2002, 177:32-39.

9. Schittek B, Hipfel R, Sauer B, Bauer J, Kalbacher H, Stevanovic S, Schirle M, Schroeder K, Blin N, Meier F, Rassner G, Garbe C: Dermcidin: a novel human antibiotic peptide secreted by sweat glands. Nat Immunol 2001, 2:1133-1137.

10. Porter D, Weremowicz S, Chin K, Seth P, Keshaviah A, Lahti-Domenici J, Bae YK, Monitto CL, Merlos-Suarez A, Chan J, Hulette CM, Richardson A, Morton CC, Marks J, Duyao M, Hruban R, Gabrielson E, Gelman R, Polyak K: A neural survival factor is a candidate oncogene in breast cancer. ProcNat/AcadSci USA 2003, 100:10931-10936.

11. Stewart GD, Lowrie AG, Riddick AC, Fearon KC, Habib FK, Ross JA: Dermcidin expression confers a survival advantage in prostate cancer cells subjected to oxidative stress or hypoxia. Prostate 2007, 67:1308-1317.

12. Stewart GD, Skipworth RJ, Pennington CJ, Lowrie AG, Deans DA, Edwards DR, Habib FK, Riddick AC, Fearon KC, Ross JA: Variation in dermcidin expression in a range of primary human tumours and in hypoxic/oxidatively stressed human cell lines. Br J Cancer 2008, 99:126-132.

13. Lowrie AG, Wigmore SJ, Wright DJ, Waddell ID, Ross JA: Dermcidin expression in hepatic cells improves survival without N-glycosylation, but requires asparagine residues. Br J Cancer 2006, 94:1663-1671.

doi:10.1186/1479-5876-9-S2-18

Cite this article as: Ross: Immune-mediated muscle wasting and cell survival - the tale of a curious gene. Journal of Translational Medicine 2011 9(Suppl 2):18.

\section{Submit your next manuscript to BioMed Central and take full advantage of:}

- Convenient online submission

- Thorough peer review

- No space constraints or color figure charges

- Immediate publication on acceptance

- Inclusion in PubMed, CAS, Scopus and Google Scholar

- Research which is freely available for redistribution

Submit your manuscript at www.biomedcentral.com/submit 